Meta

Journal des traducteurs

Translators' Journal

\title{
The Statutes of Quebec: Linguistic Interference
}

\section{Robert Russell}

Volume 24, numéro 1, mars 1979

La traduction juridique

URI : https://id.erudit.org/iderudit/004011ar

DOI : https://doi.org/10.7202/004011ar

Aller au sommaire du numéro

Éditeur(s)

Les Presses de l'Université de Montréal

ISSN

0026-0452 (imprimé)

1492-1421 (numérique)

Découvrir la revue

Citer cet article

Russell, R. (1979). The Statutes of Quebec: Linguistic Interference. Meta, 24(1),

213-217. https://doi.org/10.7202/004011ar d'utilisation que vous pouvez consulter en ligne.

https://apropos.erudit.org/fr/usagers/politique-dutilisation/ 


\section{The Statutes of Quebec : Linguistic Interference}

Linguistic interference from French is a problem that each legal transiator in Quebec must deal with as the natural result of the contact of the two legal systems in Quebec. The current laws that are translated from French to English contain a number of loans and transfers. In addition, these Statutes contain a number of couplets composed of an English term followed by its French equivalent in parentheses. Loanwords or borrowings that are not proper names are not italicized in the laws. The use of French to designate Government agencies in English context has increased greatly in the last few years and is now the primary reason for the occurrence of French borrowings.

The Statutes of Quebec contain a certain number of terms that are consistently used and printed in italics as loan-words. Legal expressions borrowed directly from French but never fully naturalized into English are few :

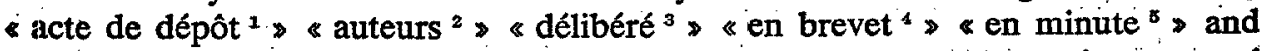
Q procès-verbal ${ }^{6} \gg$. Of these the most common by far are en minute $\gg$ and' - procès-verbal in the Statutes. Many of these are retained as loanwords in order to maintain a terminology that is consistent with the Civil Code. The new Draft Civil Code published in 1977 has abolished many of these borrowings but \& en minute $»$ and « en brevet $\$$ are still to be found along with other specialized terms such as «mainlevée ${ }^{7}$. Ecclesiastical terminology is the source of « fabri-

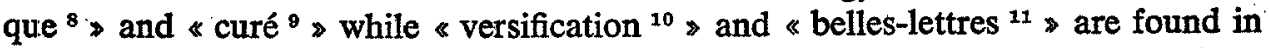
Statutes that deal with education. The term $\&$ fabrique $\gg$ occurs often in the laws that have to do with the church, appearing 43 times for example in Chapter 55 of the Statutes of 1965 , Volume I. It is always italicized. The term \& versification s has also been printed in roman type in the Statutes and enclosed in

\footnotetext{
1. The Revised Statutes of Quebec 1964, Chapter 306, section 6.

2. Ibid., Chapter 108, section 40 .

3. I bid., Chapter 20, section 13.

4. Ibid., Chapter 248, section 169.

5. Ibid., Chapter 248, section 169.

6. Report on the Quebec Civil Code, Volume I, Draft Civil Code 1977, Editeur offeiel, Québec, p. 270-272.

8. The Revised Statutes of Quebec 1964, Chapter 71, section 15p.

9. Ibid., Chapter 235, section 467 .

10. Ibid., Chapter 235, section 497.

11. Ibid., Chapter 240, section $1 \mathrm{~b}$.
} 
quotation marks while "curé » was, at times, translated. Loanwords also were furnished by areas that were not unique to Quebec culture. At racetracks in Quebec it was possible to bet under the «pari mutuel s system, a term used in the Licenses Act ${ }^{12}$. Quebec's official flag was qualified in English as \& fleurdelisé ${ }^{13}$ 》while the Statutes also contain such well respected loanwords as \& à la carte » and \& à table d'hôte ${ }^{14}$ ». The terme « cache ${ }^{15}$ » was used in the Game Act of 1964 that regulates hunting. Finally the term \& en entier o used in the French text was Englished as a en bloc * in the Securities Act of the Revised Statutes of $1964^{16}$.

Loanwords were not the only way that French words entered the English text of the laws. Translators in the past had used translation couplets, a procedure in which a translation is provided but followed immediately in parentheses with the French term. A good number of examples of this translation procedure used in the Statutes of Quebec relate to legal concepts or offices. The expression * bailiff, guardian or receiver of deposits \$ was followed in parentheses in the English text by \&uissier, gardien or receveur de consignation ${ }^{17}$ \$. Also occurring in the Statutes are witness post (piquet indicateur) ${ }^{18}$, loan (emprunt), loan (prêt) ${ }^{19}$, members (régisseurs) ${ }^{20}$, legists (hommes de loi) ${ }^{21}$, purchaser (adjudicataire) ${ }^{22}$, auditor (vérificateur) ${ }^{23}$ and delivery (dons manuels ${ }^{24}$. Rather than cases of linguistic interference, many of these couplets may be the result of an effort by the translator to ensure that the reader is informed that, for example where land claims are in question, a stake marked \&W.I. $>$ or \&.witness post $\gg$ is as valid as one marked \& P.I. » or " piquet indicateur ». The translations of emprunt * and "prêt > have not been consistent in the recent laws. Tradition had been to use the couplets to render a distinction that could not be made by translating both as \& loan . In the Forestry Credit Act of 1975 however a different solution was attempted. In the definitions to the Act « emprunt » was translated as « borrowing 》 and « prêt » as « loan ». In sections 16 through 22 of the Act however « emprunt 》 and "prêt » were both translated as \& loan * and only after section 46 was the distinction reestablished. Despite this change from couplets to translations in 1975, the simple translations were dropped in 1978 and "emprunt » and «prêt w were again translated using couplets ${ }^{25}$. The Church was another source of translation couplets for although it was decided to give no equivalent to * fabrique * other specialized terms were

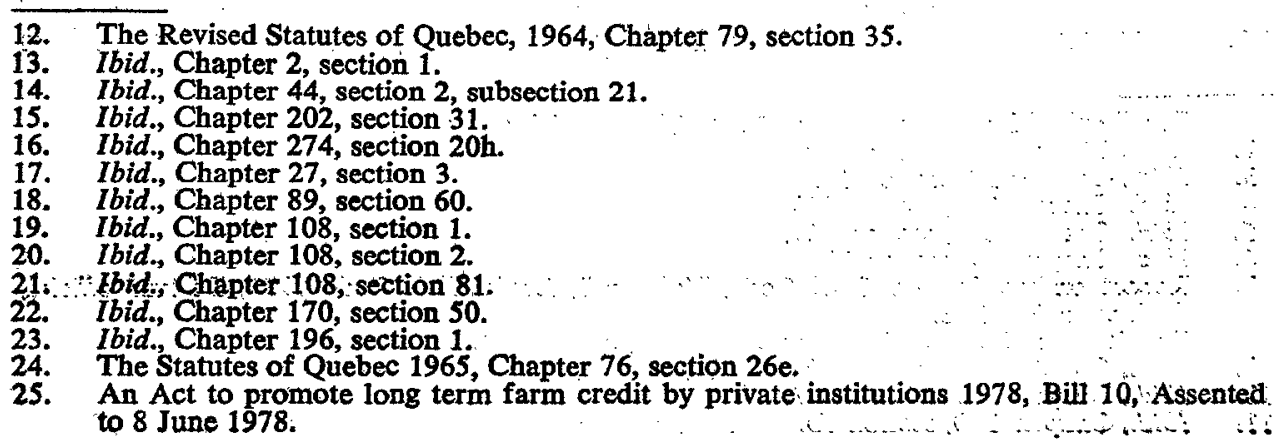


translated using couplets. This was the case for charity work rooms (ouvroirs) ${ }^{26}$, church guild buildings (patronage) ${ }^{27}$ and rector (curé) ${ }^{28}$. It is apparent that the translations of « curé \$ have not been consistent. At times a simple translation has sufficed, at times the word "cure » was borrowed into English and at times it was translated using the couplet rector (curé). Various other instances of the use of couplets can be found in the Statutes of Quebec. The University Assistance Act mentions a licentiate (la licence) ${ }^{20}$. Laws dealing with profes: sional corporations may order professionals to undergo a period of professional training during a period (stage) ${ }^{30}$. The term \& aménagement » used in sections 2 and 3 of the Public Buildings Municipal Regulation Act was construed in two different ways for which translation couplets were used to make the distinction. Section 2 mentions by-laws respecting the furnishings (aménagement) of public buildings while section 3 treats the commissions appointed to supervise their interior arrangement (aménagement).

Unlike loanwords set off in italics or parentheses, some linguistic borrowings have been completely integrated or naturalized into the legal language used in Quebec. This is the case for the term \& bâtonnier ${ }^{81}$ used to designate the presiding officer of the Barreau du Québec. In contrast, the presiding officer of the Law Society of Upper Canada is called the Treasurer, while his counterpart in Alberta is designated the President. In Quebec the Bar does not follow British tradition in naming its chief officer as does Ontario nor does it imitate the practices of other provinces. Tradition in Quebec has naturalized the term * bâtonnier » into Quebec legal terminology and it is printed in roman type in the Statutes. The word « delay » provides a somewhat different type of term that has been naturalized. Although not an essential part of legal terminology, a particular use of the word persists by dint of hard tradition. A typical use of the word as naturalized is found in the Parks Act where a park may be created if the Minister has granted \& sixty days' delay from the publication » (un delai de soixante jours à compter de la publication) ${ }^{32}$ of a notice concerning its creation. Indeed this passage is not supposed to mean the Minister postpones publication for sixty days but rather that for sixty days after publication of a notice he will accept written objections to the project. The meaning of delay as time allowed, term, period or duration does not occur in English dictionaries under \& delay * but may be found in French dictionaries under \& délai \& as in the first and third meanings provided in the Petit Robert for délai. Delay and \& delai » have been denounced as deceptive cognates by respected translators ${ }^{33}$. Another example of a term that has been borrowed and naturalized by translators is taken from the recent Automobile Insurance Act of 1977. In the definitions of the Act "garagiste " is translated as \& garagist \$ which is a term that does not appear in any dictionary - English or French. The term \& garagist used to refer to the

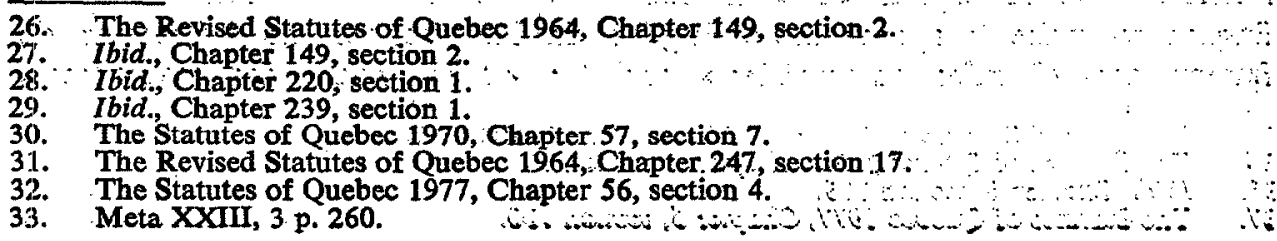


owner or operator of a garage is a borrowing that lost its final \& e when naturalized by the translator. The legal language of Quebec contains a limited number of fully naturalized borrowings some of which like « bâtonnier \& may be easily defended, others like « delay » are founded on years of tradition and a few such as « garagist $\gg$ that can only be classified as barbarisms. Increase in the number of this type of linguistic borrowing can only make comprehension of the Statutes more difficult outside Quebec.

The major difficulty to a clear reading of the Statutes of Quebec by persons not familiar with Quebec's particular legal terminology is not however the use of loanwords, couplets or naturalized linguistic borrowings but rather the exclusive use of French to designate Government agencies in English context. Section 125 of the Automobile Insurance Act (1977, chapter 68) provides an example of this type of translation:

125. The Fonds d'indemnisation is administered by the Régie; it has its corporate seat at the corporate seat of the Régie and the board of directors of the Régie shall be in lieu of the board of directors of the Fonds d'indemnisation. The provisions of the Act to establish the Régie de l'assurance automobile du Québec (1977, chapter 67) respecting the board of directors of the Régie apply mutatis mutandis to the board of directors of the Fonds d'indemnisation.

The Revised Statutes of Quebec of 1964 had provided an English translation for every Government agency. At times allowances were even made in the French text itself for an official translation as for example in the Hydro-Quebec Act :

Une corporation est créé sous le nom en français de « Commission hydro-électrique de Québec » et, en anglais de « Quebec Hydro-Electric Commission " ou l'abréviation *HYDRO-QUÉBEC ${ }^{34}$ ».

This type of official bilingualism continued until the Quebec Official Language Act of 1974 declared that all Government agencies shall be designated by their French names alone ${ }^{35}$. After that, any new agencies that were created did not receive an English name although existing English names were retained for most agencies already in existence. Thus in 1975 it is possible to find expressions such as «Société québécoise d'information juridique », the «Institut québécois du cinéma » or the "Cinémathèque nationale » among others in English context. These expressions were not printed in italics although prior to this point some Government agencies such as the «Régie de la langue française \$ were printed in italics in English context ${ }^{36}$. With the Charter of the French language (sic) the list of official agencies designated only in French lengthens. A new translation procedure appears in the text of the Charter. The expression « Assemblée nationale \$ when appearing in English context is rendered as «Assemblée Nationale ${ }^{37}>$. A capital $<N$ is added to the expression transferred into English to make it appear more English. In like manner the directeur du Bureau des véhicules automobiles, and the esurintendant des assurances,

34. The Revised Statutes of Quebee 1964, Chapter 86, section 3.

35. The Statutes of Quebec 1974, Chapter 6, section 11.

36. Ibid., Chapter 6, section 115.

37. The Statutes of Quebec 1977, Chapter 5, section 120. 
become respectively the Directeur and the Surintendent in English context ${ }^{38}$. English rules for capitalization are now applied to some parts of expressions transferred from French to English. The eministre du tourisme, de la chasse et de la pêche » has become the * Ministre ${ }^{39}$ du tourisme, de la chasse et de la pêche 》 and not the Ministre du Tourisme, de la Chasse et de la Pêche as one might expect if English rules of capitalization were applied consistently.

It is evident that French influences the English translation of the Statutes of Quebec in many ways. This is a natural and perhaps necessary state of affairs : natural in that decades of translation from French to English provided the contact that fostered individual cases of linguistic borrowing and necessary in that some legal concepts can only be rendered through loanwords. The difficult task for legal translators in Quebec is to avoid using unnecessary loanwords and barbarisms.

ROBERT RUSSELI

38. The Automobile Insurance Act, 1978, Bill 67, section 1.

39. Ibid. 